\title{
"Heav'n Hath Timely Tri'd [Her] Youth": Self-Knowledge Through Language in Milton's Comus.
}

\author{
CAROL SCHEIDENHELM
}

Our consciousness rarely registers the beginning of a growth within us any more than without us: there have been many circulations of the sap before we detect the smallest sign of bud.

George Eliot, Silas Marner

$\mathrm{J}$

ohn Milton adopts the Circe myth for his masque Comus by presenting the element of sensual pleasure opposing the virtues of continence and temperance. Comus, son of Circe and Bacchus, represents the baseness of his mother and frivolity of his father as he connives to tempt the righteous to a life of wastefulness. The Lady, a young innocent who wanders unknowingly into Comus' wood, must resist the temptations of Comus as she learns the power of language to deny her tempter. Both Comus and the Lady experience difficulties (the former in his attempted seduction and the latter in her attempts to free herself) that are the result of their misperception of language.

Milton's use of the Circe myth in masque form reflects the tradition, discussed by Lois Potter, of joining a series of dances into an "allegory of the triumph of virtue over vice". ${ }^{1}$ The basic method for the masque was to extend actuality by use of fiction, fiction developed from the "circumstances of the occasion and point [ed] back to realities" as the realities were or should have been. ${ }^{2}$ According to Don Allen, the traditional Renaissance purpose of the Circe myth was to allegorize the conflict between Nature and Reason. ${ }^{3}$ Though Milton used the masque form and its classical themes, he relied less on the visual effects than other writers of the era; Comus, when compared with more elaborate productions of the day, had a visual austerity that was thematically important. As William Oram points out, Milton was primarily concerned with what went on within the character's mind; it is the ear, not 
the eye, that has the "capacity to [translate] reasoned discourse". 4 Throughout Comus, characters and audience must evaluate the action by the dialogue, not the scenery.

This reliance on the oral rather than the visual requires a particularly careful use of language, consideration of which is crucial to an understanding of Comus. In "Of Education," Milton himself states that language is "the instrument conveying to us things useful to be known" and if man does not study "the solid things in them [language] as well as the words and lexicons he were nothing so much to be esteemed a learned man" (631). ${ }^{5}$ Ultimately it is these "solid things" within language (those elements that convey experience and tradition), not merely the "words and lexicons" that provide the focus of Milton's attention.

Psychoanalyst Jacques Lacan explores many of the same "solid things" considered by Milton. Lacan, like Milton, recognizes language as more than "words and lexicons"; indeed, Lacan states that there is no "intrinsic or natural connection between objects and words". 6 The meaning of a word, then, is learned through experienced interpretation, an interpretation Lacan ties to the subject's relationship to the "Other". The Other thus becomes the definer of the subject's understanding of language: it is the Other's discourse that controls the subject's speech. If a subject "has not been solidly grounded by a symbolic identification with the [Other], [the subject] fails to support the grammatical language structures that we equate with interactional discourse and with cognition". ${ }^{7}$ Failure to properly use the accepted discourse results in dysfunction of the subject in society.

This societal dysfunction may be seen in the character Comus, as he represents a total disregard for the societal Other accepted by the Lady, the other characters, and the audience. Although Comus enters in to the society of the Other and interacts with its members, Lacan would consider him dysfunctional because of Comus' refusal to accept the authority of the language of the Other. In Milton's masque, the societal Other is Reason reason to control the power of the will over the temptations of the physical self of nature. Comus' rejection of Reason places him in a sub-society where a new order of "Reason" is formulated - reason that will rationalize the wantonness of the subculture's members. Rosemond Tuve supports this sub-culture premise when she states that Comus and his rabble do not see Reason in the traditional way. ${ }^{8}$ To communicate his "Reason," Comus must employ a language, mocking that of the societal Other, but reflective of the authority of his adopted Other, Pleasure. 
There is an ironic dichotomy between the acceptable language of the Other and the discourse of Comus, however, as their values are opposites on the scale of morality. The concepts of temperance and continence inherent in the Lady's moral attitudes presuppose the wantonness of Pleasure, as without Pleasure there is no need for virtue. The Lady and Comus become the interlocutors in a dialogue that ironically uses the same lexicons but with vastly different meanings. In Comus' lexicon of subversive language, the experiential meaning is far different. This difference is not fully understood by the tempter, however, perhaps because, as Milton points out in 11 73-75, Comus' loss of reason is accompanied by a loss of self-knowledge. Comus feels his language is "baited with reasons not implausible" $\left(\begin{array}{ll}1 & 161\end{array}\right)$ but also realizes that in order to get his prey to listen he must "cheat the eye with blear illusion,/ And give it false presentments, lest the place/ And my quaint habits breed astonishment" (11 155-57). The anti-hero recognizes the difference in his costume and realizes that his appearance will influence the approaching virgin, but he is convinced his "reasons not unplausible" will speak for themselves. Because Comus is so confident in the appeal of his language (his temptations) he is sure his words alone will woo the lady into submission: "I'll speak to her/And she shall by my Queen" (11 264-65). His lead-up speech, filled with sensual images of fertility and ravishment, is antithetical to the societal Other, yet Comus is convinced that his words will appeal to his victim and conquer Reason. Comus' limited self-knowledge allows him to see that man must be deceived and tempted to his sub-societal Other, but he ties that deception to his appearance and the form his language takes (he recognizes the rhyme of his introductory speech will arouse suspicion) ${ }^{9} \mathrm{He}$ is not, however, able to understand the extent to which the sensual nature of his language differs from the foundation of the language of the Other.

Early in the masque, Comus illustrates the difference between his language and the language of the Other. Upon his initial entrance, Comus summons Cotytto, Goddess of Nocturnal sport: "Dark veil'd Cotytto, t'whom the secret flame/ Of midnight Torches burns; mysterious Dame,/ That ne'er art call'd but when the Dragon womb/ Of Stygian darkness spits her thickest gloom" (11 129-132). In this invocation, Comus calls upon the realm of the subhuman, the "Dragon womb," reducing human nature to the merely animal. But Comus is unconcerned with what his summons evokes; Comus' discourse of choice is understood to be what Comus himself accepts: the societal Other be damned. ${ }^{10}$

Though the difference between the intent of Comus' language and the language of the Other is significant, the difference is not perceived by the 
Lady, who initially is deceived by his discourse. According to Tuve, Milton often espoused the strain that "evil works by assuming the very form and reason of good". ${ }^{11}$ The inexperienced Lady mistakes both reason and form: "Shepherd, I take thy word,/ And trust thy honest offer'd courtesy" (11 322-23). Her first mistake is to view Comus as a shepherd, protector of the vulnerable. She states that the rustic surroundings and his honest courtesy are more protection than the Courts of Princes can supply. Her second error is to take his word as the word of the societal Other; though the grammatical units spoken by Comus are recognizable, their meaning is on a plane beyond the Lady's comprehension. The language of Comus is not pastoral, as the Lady assumes, but a "wonted roar" (1 549) as described by the more experienced attendant spirit. It is not until the Lady is enthroned in the enchanted chair, surrounded by the extravagances of Comus' court that she recognizes her errors. She accosts her tempter with the strength of the language of the Other: "false traitor,/'Twill not restore the truth and honesty/ That thou hast banish't from thy tongue with lies" (11 690-92). What the Lady still does not recognize is that the language of Comus is not a lie to him and his courtiers, as they have rejected the language of the societal Other.

Lacan explains a subject's failure to function in society as a result of the subject's rejection of the language of the Other. It is obvious that Comus functions well in his own, self-created society, but his rejection of the Other prohibits his acceptance in conventional society. Common discourse enables members of society to interpret life experiences by Reason. The interpretation is possible because the Other sets the guidelines and parameters. Comus' failure to remain within the perimeters of the Other removes him from accepted society. Lacan would say that Comus' rejection of the Other causes him to be dysfunctional. His refusal to use the discourse of the societal Other causes him to fail in his attempt to seduce the Lady, and his rejection of Reason takes away his power to communicate in man's discourse. That man will occasionally yield to his temptations illustrates the failure of man more than the power of Comus. ${ }^{12}$

One major flaw in Comus is that he can not accept the control that Reason represents. A.S.P. Woodhouse states that Comus appeals to nature in an attempt to undermine the virtue of continence (self-restraint). ${ }^{13}$ In his subhuman discourse, Comus claims that nature's abundance is provided for man to enjoy unrestrictedly: "Wherefore did Nature pour her bounties forth/... But to please and state the curious taste?" $(11710,714)$. What his words do not say, however, is what his language reflects: nature is to be enjoyed for gratification with no sense of responsibility - no controlling Reason. Trapped 
in Comus' palace, the Lady realizes the absence of a system of checks and balances as she states, "I hate when vice can bolt her arguments,/ And virtue has no tongue to check her pride" (11 760-61). Comus is surprised and puzzled by the Lady's resistance to what seems to him a perfectly rational theory of nature's intent. In his final speech (11800-813) Comus realizes that the discourse of the Lady represents a power superior to his own, but he is unable to accept her societal Other. He recognizes the lexicons being exchanged as "moral babble" and accuses the Lady of attacking "the canon laws of our foundation" (1 808). What he does not understand is that he and the lady operate under separate canons: "our foundation" - or a common discourse - is, for the two of them, non-existent.

The Lady, like Comus, does not fully understand the lack of a common discourse. She is initially deceived by Comus partly because she does not understand that a language exists outside the control of the Other, and partly because she has not established her own relationship to the Other. The Lady's misperceptions are a symptom of her inexperience and lack of selfknowledge, the latter being viewed by several critics as evident in her invocation of the nymph Echo. Angus Fletcher views the invocation as crucial to the masque: the Lady appeals to an Echo that does not reply, but her liberation depends on a reply. ${ }^{14}$ But a reply from Echo would be merely a reflection of the Lady's own voice, the narcissistic self impotent to teach the Lady the discourse of the Other. The Lady appeals to a "heavenly harmony asking to be freed from her own echo chamber", 15 a request that is ironic because of its impossibility: the Lady is trapped within her own thoughts and appeals to Echo to free her from herself. In theory the Lady is correct, as the freedom she seeks must come from within; but freedom will not be produced by an echo of what already exists.

When Echo does not answer the summons, the Lady seeks another outside source of knowledge; Comus is first on the scene and is subsequently believed, his discourse embraced as the language of the Other. When the Lady enters Comus' palace and understands the "wonted roar" of his discourse, she gains knowledge on two planes: first, she discovers that she has embraced a false shepherd whose words reject the Reason demanded by the Other; second, she begins to investigate her inner-strength and its relation to the Other. Her brothers and the attendant spirit have made much of the power of Chastity to overcome evil and, initially, the Lady recognizes Chastity as the Reason imposed by the Other. The language of the Other has made her rhetorically superior to Comus, yet she still takes his words as a serious threat. As she views this power, she evaluates her position and analyzes her 
capabilities: the "freedom of [her] mind" (1 663) to employ Reason to control her will makes her powerful enough to resist the physical enticements of Comus (she remains temperate and continent) but she is still influenced by his language. Enthroned in the tempter's chair, the Lady recognizes the failure of Comus to function within the perimeters of the Other. She also discovers her own separate nature and how she relates to the Other: an inner-struggle between self and Other begins.

Though most critics contend that it is the evil magic of Comus that binds the Lady to the throne, a careful look at the masque suggests that it may be the Lady, herself, who inhibits her own movement. The stage directions preceding Comus speech (11 659-662) state that the Lady sets the offered Glass aside and goes to rise. Comus speaks and warns her not to try to move: "Nay, Lady, sit; IF I but wave this wand,/ Your nerves are all chain'd up in Alabaster" (emphasis mine). At this point the Lady is still able to move and Comus only threatens to wave his wand. The Lady imagines herself trapped by his "charms, although this corporal rind/ Thou has immanacl'd" (11 664-665). Although Comus speaks no magic words and does not wave his wand, the Lady appears unable to move. This suggests that the power of Comus' discourse is enough to force the Lady to evaluate her position in terms of both Comus and the Other. The conflict caused by denying Comus and evaluating the discourse of the Other disables her physical self and disallows her movement. In rejecting Comus, she upholds the dictates of the language of Chastity and Temperance and denies her own physical nature.

The severity and consequences of the Lady's denial give further insight into the young woman's search for self. Oram contends that the Lady is on her guard because of her early misinterpretation of Comus' intent, and that her denial reflects a shift from the "virtue identified with love of one's fellow man to one associated with self-restraint". The critic further suggests that Comus intrudes on the Lady's consciousness, arousing in her an exaggerated severity of denial. ${ }^{16}$ Oram's statements suggest that as the Lady is speaking to Comus she is simultaneously searching her consciousness for self-identity. Her rhetorical defense of chastity is her attempt to both define the language of the Other and come to terms with it.

This self-discovery is discussed by Fletcher, who contends that at the moment of her self-recognition, the Lady realizes that Chastity is the virtue imposed by society for the world outside the self; virginity, however, "leads to an interior knowledge of one's inner life". ${ }^{17}$ Chastity becomes, then, the language of the Other and virginity the language of the self. She is not able 
simply to reject the physical by denial, but must internalize the rationale for her rejection - a far cry from the echo she seeks early in the masque.

Through the power of the language of the Other, the Lady works her way through a defence of the virtues of Chastity and continence-Reason's control over the physical - but the Lady does not attempt an explanation of the doctrine of Virginity. The Lady claims that Comus "hast not the Ear nor Soul to apprehend/ The sublime notion and high mystery" (11 784-85) of the sacred doctrine. She knows he would not understand the language behind the concept because of his own "dear Wit and gay Rhetoric/ That hath so well been taught her dazzling fence" (11 790-91). But Potter suggests another interpretation of the Lady's silence, stating that the Lady's concept of virginity can not be explained because her perception is mystical rather than physical. ${ }^{18}$ I take Potter's argument a step further: The Lady denies a rhetorical response because she is unable to internalize her understanding of the doctrine of Virginity. She understands the concept intuitively but is unable to put her knowledge into speech, defending her silence with the claim that Comus is not worthy of an explanation. Her error is in her assumption that an intuitive grasp is sufficient. She fails to see the importance of self-knowledge: the Lady has yet to interpret Virginity as it relates to her. It is not the magic of Comus that imprisons her in the throne of the pleasure palace, but her own denial of the sensual and her search for a relationship to the Other that act as manacles.

The ability to free the Lady who imprisons herself can not come from her rescuers, the young brothers and attendant spirit. The brothers succeed in breaking the Glass and spilling the evil drink, but they fail in their attempt to secure Comus' wand, the wand that represents the power to imprison the Lady. ${ }^{19}$ The spirit leads the brothers off to find Sabrina, symbol of Virginity, to help the Lady free herself. Oram states that Sabrina, symbol of man's lower nature positively transformed, is necessary to instruct the Lady in resolution of her conflict between sensual nature and chaste authority. Sabrina's experience has taught that the conflict between human spirit and Reason can be harmonious. ${ }^{20}$ It is the lesson of Sabrina that helps the Lady define her virginity as it relates to the authority of the Other and to her self. This self-knowledge comes through the anointment by Sabrina, teaching the Lady the power of discursive Reason to resolve the struggle between the sensuous and the reasonable. Sabrina leaves behind not a changed scene but a changed mind.

Milton's explorations into the language of Comus and the Lady are typical of the poet's concern with "what goes on with in the mind, in bringing 
reasoned change". ${ }^{21}$ Comus rejects the discourse of the Other and displaces Reason with his own guidelines. These parameters, however, disregard the very power that could make him part of society. Comus' failure to seduce the Lady - his attempt to have her accept his language of incontinence - results from his rejection of the Other's reason. The reader should not be tempted to pity the displace antagonist, however, for, as Milton tells us, Comus and his rabble have lost self-knowledge with their Reason and are content in their ignorance. There will be other prey to ply with the pleasures of excess.

The story of the Lady differs from that of the unchanging Comus: hers is the story of one who uses Reason to improve self-knowledge. The Lady is on the beginning edge of self-knowledge; the "unpolluted temple of the mind" (1 461) is a sealed cave ready to be opened and explored and her mind will need to be continually testing the power of the discourse of the Other. The tale ends as the Lady returns safely home to the parental sanctuary, but just as the lady's experiences in Comus force her to continually reinterpret language - the language of Comus, of her self, and of the Other - until she recognizes and defines her self, her life will require on-going self-exploration of the "unpolluted temple."

\section{Northern Illinois University}

\section{Notes}

1. Lois Potter. A Preface to Milton. (New York: Charles Scribner's Sons, 1971), p. 92.

2. C. L. Barber. "A Mask Presented at Ludlow Castle: The Masque as a Masque," in Joseph Summers, ed. The Lyric and Dramatic Milton (New York: Columbia University Press, 1965), p. 39.

3. Don C. Allen. "The Higher Compromise: On the Morning of Christ's Nativity and A Mask." in John Diekhoff, ed. A Maske at Ludlow: Essays on Milton's Comus" (Cleveland: Press of Case Western Reserve University, 1968), 58-71. The significance to the Renaissance of the Nature/Reason conflict is investigated by E.M.W. Tillyard, who restates the Elizabethan idea that will is a result of nature, and reason is the tempering agent of will. Tillyard states, "it is not in our power not to be stirred mentally by our appetites [Nature] but it is in our power to translate them or not to translate them into action" (73). The critic further contends that only through the diligence of reason can man come to the understanding that will can be victorious in the struggle between passion and reason (74).

4. William Oram. "The Invocation of Sabrina," Studies in English Literature, 24.1 (1984), 121-139.

5. This, and all subsequent Milton quotes, from the 1957 Merritt Hughes edition of John Milton Complete Poems and Major Prose. 
6. Ellie Ragland-Sullivan. Jacques Lacan and the Philosophy of Psychoanalysis (Chicago: University of Illinois Press, 1987), p. 198.

7. Ellie Ragland-Sullivan. Op. cit., p. 199.

8. That Comus' Reason is a distortion of the real is further illustrated in $11297-98$, where Comus tells the Lady he has seen her brothers and mistaken them for "more than human creatures: I took it for a faery vision." The possibility exists that his account is romanticized in his continued attempt to woo the young woman, but his choice of images is consistent with the discourse of frivolity he espouses.

9. Comus' introductory speech is delivered in rhymed couplets. With the exception of the spirits closing speech, only the songs are presented in rhymed form. When Comus hears the Lady approaching he breaks off his rhymes and speaks in conventional form, suggesting that he does not wish to arouse suspicion by using exceptional speech patterns.

10. Many critics view as a counterpart to Satan, but viewing Comus as a work apart from the Milton tradition that follows, allows us to see this hedonistic creature as evil (because of his efforts to bring man to the level of his rabble) but not vindictively Evil (wishing revenge on God) as Satan. The masque itself suggests that Comus represents the desire of man to function only for the fulfilment of pleasure. The sensuous nature of Comus' speech does not reflect a bitter rejection of authority (as Satan's vengeful tirades) but an indifference to the laws of the societal Other.

11. Rosemond Tuve. "Image, Form and Theme in A Masque." in Images and Themes in Five poems by Milton (Cambridge: Harvard University Press, 1962), p. 127.

12. Tuve points out that the Circe myth was used to convey seduction by one's own appetites (p.140).

13. A. S. P. Woodhouse. "The Argument of Milton's Comus." (1941); Milton: "Comus" and "samson Agonistes." Ed. Julian Lovelock. (London: Macmillan, 1975), p. 45.

14. Angus Fletcher. The Transcendental Masque: An Essay on Milton's "Comus" (Ithaca: Cornell University Press, 1971), p. 199.

15. Angus Fletcher. Op. cit., p. 200.

16. William Oram. Op. cit., p. 132.

17. Angus Fletcher. Op. cit., pp. 215-6.

18. Lois Potter. Op. cit., p. 120.

19. Because Comus and Circe have traditionally used the wand to increase their "herds" of rabble, the attendant spirit is not unfounded in his belief that they must secure the wand and reverse the spell.

20. William Oram. Op. cit., p. 131.

21. Ibid., p. 136. 